
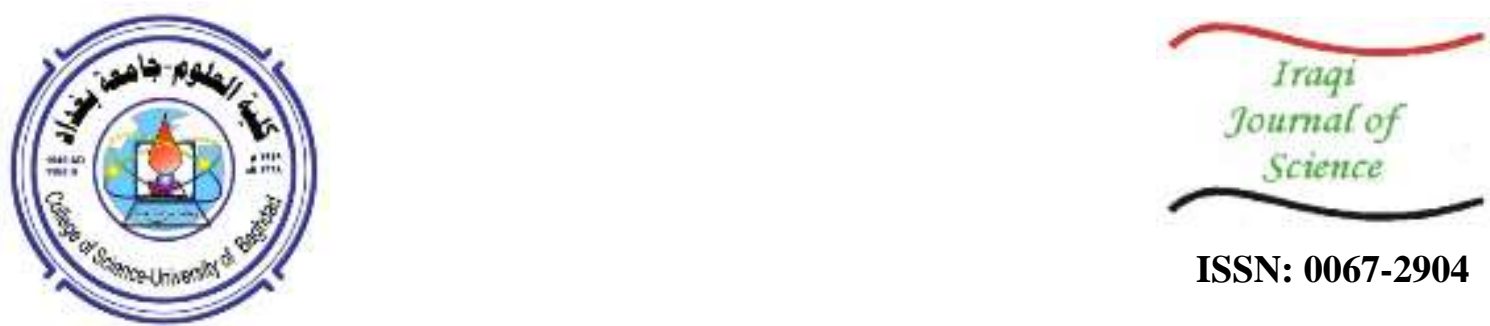

ISSN: 0067-2904

\title{
Assessment of Genotoxicity of Citrobacter freundii Bacteriocin on Bone Marrow Cells in Albino Mice
}

\author{
Rasha Noori Hammad*, Hind Hussein Obaid \\ Department of Biology, College of Science, University of Baghdad, Baghdad, Iraq
}

\author{
Received: 3/11/2019 Accepted: 21/1/2020
}

\begin{abstract}
Genotoxic effects of crude bacteriocin extracted from Citrobacter freundii were detected on albino mice bone marrow cells in vivo, using micronucleus (MN) and comet assay. The mice were administered intraperitoneally with 37.5, 75, 150 and $300 \mathrm{mg} / \mathrm{kg}$ of the extract for 24 hours. C. freundii was isolated from patients suffering from urinary tract infections (UTI). The bacteriocin producing isolates were determined using cup assayand the most efficient bacteriocin producers were selected. Bacteriocin was extracted from the efficient isolates via the induction with Mitomycin-C $(2 \mathrm{mg} / \mathrm{ml})$. Bacteriocin activity $(320 \mathrm{U} / \mathrm{ml})$ was determined by well diffusion method, while the protein concentration $(2900 \mu \mathrm{g} / \mathrm{ml})$ was estimated by Lowery method. The results showed an acute dose-dependent toxic effect of the crude bacteriocin ; The higher doses $(150$ and $300 \mathrm{mg} / \mathrm{kg})$ caused a significant increase $(\mathrm{P} \leq 0.05)$ in the micronuclei frequency in the bone marrow cells $(4.62$ and $5.37 \%$, respectively ). Furthermore, DNA damage increased significantly $(\mathrm{P} \leq 0.05)$ and proportionally to higher bacteriocin doses $(75,150$ and $300 \mathrm{mg} / \mathrm{kg}$ ), as demonstrated by increased values of tail length $(145.18,267.73$ and $295.08 \%$,) $\%$ DNA in tail $(8.05,13.87$ and $14.31 \%)$, and olive tail moment $(13.25,22.72$ and $25.85 \%$, respectively.
\end{abstract}

Keywords: Genotoxicity, Citrobacter Freundii, Bacteriocin, Bone Marrow Cells, Micronucleus(MN), Comet Assay.

تقييم السمية الجينية لبكتريوسين بكترياCitrobacter freundiiفي خلايا نخاع عظم الفئران البيض

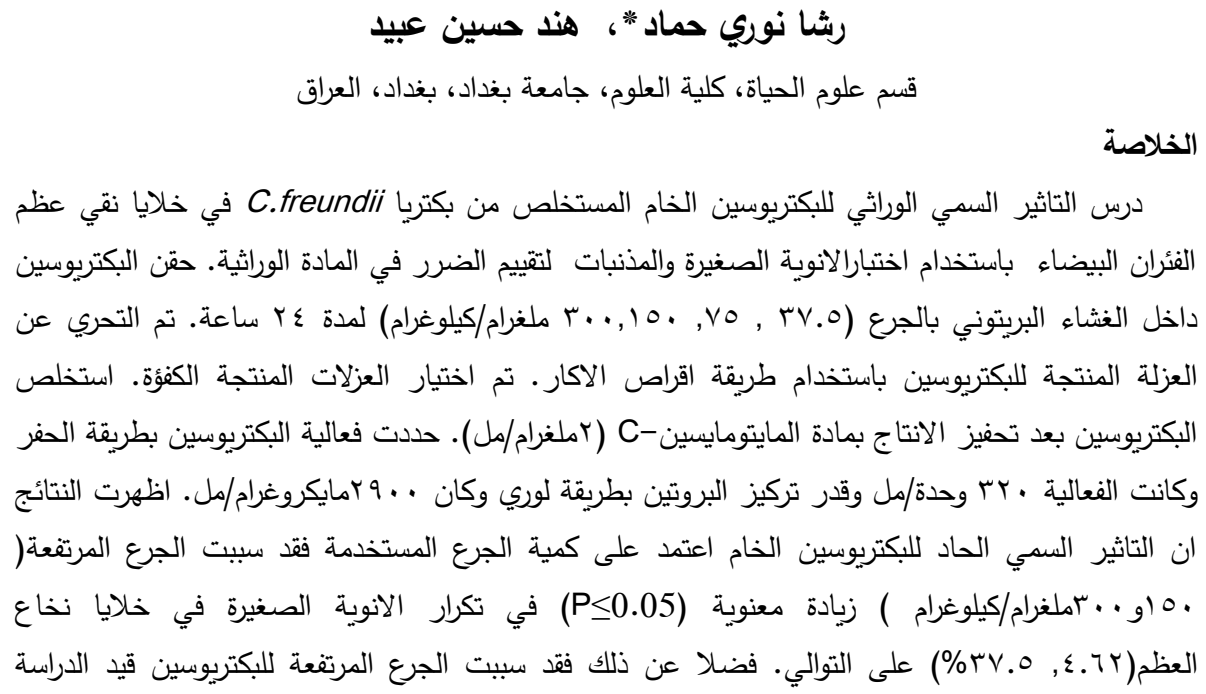




$$
\begin{aligned}
& \text { ارتفاعا معنويا (PS0.05) في الضرر الحاصل في المادة الوراثية في خلايا نخاع العظم تتناسب طرديا مع }
\end{aligned}
$$

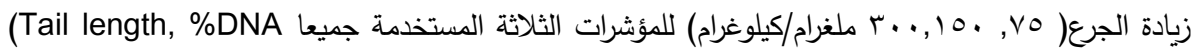

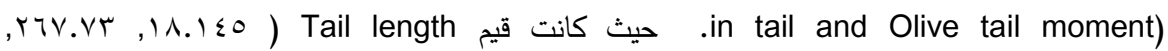

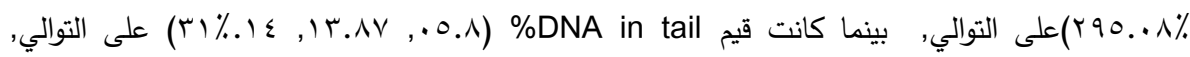

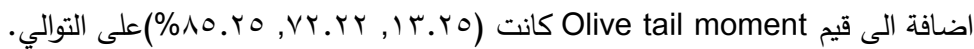

\section{Introduction}

Citrobacter freundii is a member of the genus Citrobacter within the family Enterobacteriaceae, which is present in the gastrointestinal tract of animals and human. It might become an opportunistic pathogen which causes urinary tract infection, diarrhea, peritonitis, meningitis, bacteremia and brain abscess $[1,2]$.

Bacteriocins are proteinaceous or antimicrobial peptides, ribosomally-synthesized by producing bacteria to inhibit the growth of a closely related bacterial strain. It is secreted to the extracellular medium where they recognize specific receptors on the surface of sensitive bacterial cells $[3,4]$. There are more than 2000 different antimicrobial peptides (AMPs) produced by a diversity of living organisms. Bacteriocins produced by bacteria are a minor group, whose chemical structure is most complicated among all AMPs. Currently, about 280 different bacteriocins are known [5].

Gratia first discovered bacteriocins in 1925, when he was searching for approaches to kill bacteria and observed that E.coli $\mathrm{V}$ can inhibit the growth of E.coli $\mathrm{S}$. They were primarily termed as colicins and, later, their proteinaceous nature was resolved in 1946 by Fredericq who also demonstrated that the inhibitory activity of bacteriocins was due to the presence of specific receptors on the surface of sensitive cells [6,7]. Some investigators prefer separating 'true' bacteriocins, such as colicins and colicin-like bacteriocins, from so-called bacteriocin-like inhibitory substances (BLIS) [8]. There is a continuing interest in bacteriocins from lactic acid bacteria (LAB), and some authors suggest a sub classification for these AMPs [9]. Moreover, the broad variety of bacteriocins, their origins, complexities of production, and mechanisms of actions, justify the need for sub classifications for several other groups of bacteriocins [10].

Several previous studies confirmed the lethal effect of bacteriocins on sensitive bacterial cells such as Pseudomonas aerugensa, Klebsiella pneumonia, E. coli and others [11,12]. Due to the prokaryotic cells which, requires specialized receptors to bind the protein to the target cells, bacteriocins have multiple targets to sensitive cells such as the biosynthetic apparatuses of the cells and bacterial membranes [13]. This fact led the researchers to investigate the effects of bacteriocins on eukaryotic cells such as mammalian cells that do not have a cell wall [14]. The lethal effect of these bacteriocins on eukaryotic cells could be through the effect on the plasma membrane, = the genetic material (DNA), or the process of protein synthesis through the effect on RNA [15]. The toxic effect of bacteriocins toward mammalian cells depends on the type of cells, the type of bacterium, the time of exposure and the concentration used. In general, normal cells are more resistant to the effect of bacteriocins than cancer cells because of the modifications that take place in the size and shape of cancer cells which become carriers of specialized receptors for the binding of bacteriocins [16,17].

A study conducted by Cebrián et al. [18] on the toxicity of AS-48 bacteriocin on human erythrocyte showed that the hemolytic potential of AS-48 bacteriocin varied with the concentrations used; hemolysis produced at the higher concentration $(20 \mu \mathrm{M})$ was very low (less than $1.2 \%$ ), whereas no hemolysis occurred at a low concentration of $5 \mu \mathrm{M}$. Smarda et al. [19] conducted a study on the effect of colicin E on Euglena gracilis, which falls within the flagellum class. They concluded that Colicin $\mathrm{E}_{2}$ inhibits the proliferation of these cells by breaking down DNA into pieces. A study by Naghmouchi et al. [20] reveled that nicin A and pediocin PA-1/AcH bacteriocins reduced colistin toxicity on Vero cells as well as its hemolytic activity on fresh human RBCs.

\section{Materials and methods}

\section{Bacterial isolation and identification}

Citrobacter freundii isolates were obtained from 150 patients suffering urinary tract infection (UTI) referred to AL-Yarmuk Teaching Hospital in Baghdad. The urine samples were cultured on MacConkey agar and Eosin Methylene Blue agar for $18-24 \mathrm{hrs}$. at $37^{\circ} \mathrm{C}$ for primary identification. The appearance of the G-ve isolates was identified dependent on microscopic, cultural and 
biochemical tests (catalase, oxidase, indole, methyl red, vogas-proskaurs, citrate, urease, kliglar iron agar (KIA), lactose fermentation) [21], as well as chromogenic agar and Vitec-2 system.

\section{Detection of $C$. freundii bacteriocin-producing isolates by cup assay}

The isolates of Citrobacter were subjected to a screening process that was performed to investigate their competitive activities to inhibit the growth of a sensitive isolate $(E$. coli). The ability of these isolate to produce the bacteriocin was assayed using the cup assay. The isolates were cultured in brain heart infusion broth with $5 \%$ glycerol and incubated at $37{ }^{\circ} \mathrm{C}$ for $18 \mathrm{hrs}$. After the incubation period, the growing bacterial isolates were heavily streaked on brain heart infusion agar $+5 \%$ glycerol and incubated at $37{ }^{\circ} \mathrm{C}$ for $18 \mathrm{hrs}$. An indicator isolate suspension was prepared and compared with 0.5 McFarland standard solution. The suspension of the indicator isolate was spread on the surface of nutrient agar and left to dry at $37^{\circ} \mathrm{C}$ for $10 \mathrm{~min}$. Each isolate was plated in a duplicate. A cork porer (5 $\mathrm{mm}$ diameter) was used to make discs on the brain heart infusion agar that contains the producer isolates. The discs were removed from the agar medium, translocated gently on the surface of nutrient agar spread by the indicator isolate, and incubated overnight at $37^{\circ} \mathrm{C}$. The efficient bacteriocinproducing isolates were selected depending on the size of the inhibition zone around the agar disk against that produced by the indicator isolate [22].

\section{Extraction of crude $C$. freundii bacteriocin [23]}

Test tubes were cultured with the efficient isolates, each containing $2.5 \mathrm{ml}$ of the sterile brain heart infusion broth, and incubated at a temperature of $37^{\circ} \mathrm{C}$ for 18 hours; A liquid medium of heart infusion broth $(100 \mathrm{ml})$ with $5 \%$ glycerol was distributed in appropriate flasks. Inoculations of the bacterial cells were cultured in the first step $(2.5 \mathrm{ml})$, then incubated in a shaker incubator $(150-200 \mathrm{cycle} / \mathrm{min})$ at $37^{\circ} \mathrm{C}$ until the cells reached about $3 \times 10^{8}$ cells / $\mathrm{ml}$ after $14 \mathrm{hrs}$. at. After the end of the incubation period, mitomycin- $\mathrm{C}$ was added with a final concentration $2 \mathrm{mg} / \mathrm{ml}$ to induce bacteriocin production , followed by another shaking incubation step for 3 hours. The culture was centrifuged at $5000 \mathrm{rpm}$ for $30 \mathrm{~min}$ in a cooling centrifuge. Chloroform was added for the killing of any cells that might be found in the supernatant. All supernatants were cultured on brain heart infusion agar in order to confirm the absence of any cells. Thereafter, they were stored at $4^{\circ} \mathrm{C}$ until used. The supernatant was taken to evaluate bacteriocin activity using the well method [24] and the concentration of protein was determined using Lowery method [25].

\section{Genotoxicity effects of $\boldsymbol{C}$. freundii bacteriocin in albino mice}

Six to eight weeks old albino male mice (weighed 25-30 gm) were used. Mice were supplied from the Iraqi Center for Cancer and Medical Genetics Research. All the living conditions were provided including diet and drinking water under controlled conditions of $25 \pm 5^{\circ} \mathrm{C}$ and $12 \pm 2$ hours light/dark cycles. Different doses of bacteriocin were prepared (37.5, 75, 150 and $300 \mathrm{mg} / \mathrm{kg}$ ) according to the $\mathrm{LD}_{50}$ of $C$. freundii bacteriocin which was previously determined [26]. Animals were injected intraperitoneally with $0.3 \mathrm{ml}$ of each of these doses (Three mice for each concentration), while the control mice were injected with $0.3 \mathrm{ml}$ of normal saline. After $18 \mathrm{hrs}$., the animals were sacrificed by cervical dislocation and dissected to obtain the femur [27].

\section{Micronucleus assay} [28].

Cytogenetic analysis of the $\mathrm{MN}$ in the bone marrow was conducted using standardized procedures

The femoral bones of each mouse were excised, the surrounding muscle was trimmed, and both ends of the bone were cut to collect the bone marrow cells. Bone marrow cells were flush out with 1 $\mathrm{ml}$ of inactivated fetal calf serum (FCS) into Eppendrof tubes using a $1 \mathrm{ml}$ syringe. Then, the tubes were centrifuged at approximately $1000 \mathrm{rpm}$ in a micro centrifuge for $5 \mathrm{~min}$. The supernatant was removed and the cells were resuspended with $500 \mu \mathrm{l}$ of FCS. A volume of $50 \mu \mathrm{l}$ of cell suspension was placed on the end of a glass slide, spread to make a smear, fixed with methanol, and stained with Giemsa stain. Finally, the percentage of MN was calculated using the following equation: MN\% = (Number of MN cells /100) $\times$ 100.Alkaline comet assay

Bone marrow was collected from the femur bone through injection with warm PBS $\left(37^{\circ} \mathrm{C}\right)$. The cells suspension was of a final concentration of $1 \times 10^{5}$ cells $/ \mathrm{ml}$. Low melting agarose (LM) was melted in a beaker of boiling water for 5 minutes and placed in $37^{\circ} \mathrm{C}$ water bath for at least 20 minutes to cool. Cell suspension was mixed at $1 \times 10^{5} / \mathrm{ml}$ with molten $\mathrm{LM}$ agarose $\left(37^{\circ} \mathrm{C}\right)$ at a ratio of $1: 10(\mathrm{v} / \mathrm{v})$ and $50 \mu \mathrm{l}$ of the mixture was immediately pipetted on a comet slide. Flat slides were kept at $4^{\circ} \mathrm{C}$ in the dark for 10 minutes. Afterwards, a $0.5 \mathrm{~mm}$ in diameter clear ring appeared at the edge of the 
comet slide. Slides were immersed in $4^{\circ} \mathrm{C}$ lysis solution for 30-60 minutes and then in Alkaline Unwinding Solution for 20 minutes at room temperature or for 1 hour at $4^{\circ} \mathrm{C}$, in the dark. For the comet assay electrophoresis (ES-unit), $\sim 850 \mathrm{ml}$ of $4^{\circ} \mathrm{C}$ Alkaline Electrophoresis Solution was added, then the slides were placed in an electrophoresis slide tray. Power supply was settled to 21 volts for 30 minutes. Excess electrophoresis solution was drained gently and the samples were immersed twice in dissolved $\mathrm{H}_{2} \mathrm{O}$ (after $\mathrm{NaOH}$ is dissolved) for 5 minutes each, then in $70 \%$ ethanol for 5 minutes. The samples were then dried at $37^{\circ} \mathrm{C}$ for $10-15$ minutes. $100 \mu \mathrm{l}$ of diluted SYBR Green was placed onto each circle of dried agarose for 30 minutes (room temperature) in the dark. Slides were dried completely at $37^{\circ} \mathrm{C}$ and viewed by fluorescence microscopy.

Quantification was performed using image analysis software comet score, which calculates different parameters for each comet. Three parameters were estimated, which were tail length, \%DNA in tail and olive tail moment. Olive tail moment is defined as the product of the tail length and the fraction of total DNA in the tail $[29,30]$.

\section{Statistical Analysis}

The Statistical Analysis System- SAS 2012 software [31] was used to detect the effect of difference factors in the studied parameters. The results were expressed as mean \pm S.D.. Least significant difference (LSD) test (Analysis of Variation-ANOVA) was used to compare between means in this study.

\section{Results and discussion}

\section{C. freundii Bacteriocin-producing isolates}

Percentage of $C$. freundii isolated from UTI patients was $2 \%$ of the total isolates. $C$. freundii bacteriocin producers, as detected by the cup assay, exhibited a mean inhibition zone of $30 \mathrm{~mm}$, whereas the extracted bacteriocin yielded a protein concentration of $2900 \mu \mathrm{g} / \mathrm{ml}$ and an activity at 320 $\mathrm{AU} / \mathrm{ml}$.

\section{Effect of $C$. Freundii bacteriocin on MN frequency}

C.freundii bacteriocin caused a significant increase $(\mathrm{P} \leq 0.05)$ in $\mathrm{MN}$ frequency $(5.37 \pm 0.79 \%)$ at a dose of $300 \mathrm{mg} / \mathrm{kg}$ as compared to the control (3.55 $\pm 0.57 \%)$, while $\mathrm{MN}$ frequency was $3.87 \pm 0.86 \%$ at a dose of $37.5 \mathrm{mg} / \mathrm{kg}$ at. No significant differences were recorded between the MN frequency of the control and the bacteriocin at the doses of $37.5,75$ and $150 \mathrm{mg} / \mathrm{kg}(3.87 \pm 0.86,4.05 \pm 0.95$ and 4.62 $\pm 0.56 \%)$. In addition, no significant differences were observed among the used doses $(37.5,150$ and $300 \mathrm{mg} / \mathrm{kg}$ ) (Figure-1).

Micronuclei are formed as a result of chromosomal aberrations and acentric fragments excluded from the main nucleus on late stages of anaphase. MNs can be produced through the two mechanisms of chromosomal breaks (clastogenesis) or distruption of the mitotic apparatus (aneugenesis). MNs are used in the detection of cytogenetic damages in inhabitants exposed to genotoxic agents. It can be also implemented in the detection of polychromatic erythrocytes in vivo [32-34].

The results of this study observed that the higher doses $(150$ and $300 \mathrm{mg} / \mathrm{kg})$ of C. freundii bacteriocin elicited significant increases in MN frequency in the bone marrow of mice. This indelicate segregation of chromosomes may result from hypo-methylation of repeat sequences present in DNA, dysfunctional spindle apparatus, or irregularities in kinetochore proteins or their assembly. The resulting MN frequency could potentially arise to increased DNA repair proficiency, a decrease in the number of cellular DNA double strand breaks, an increase in cellular proliferative index, increased apoptosis of erythroblasts, or harboring DNA damage, based on the length of the erythrocyte cell cycle $[35,36]$. 


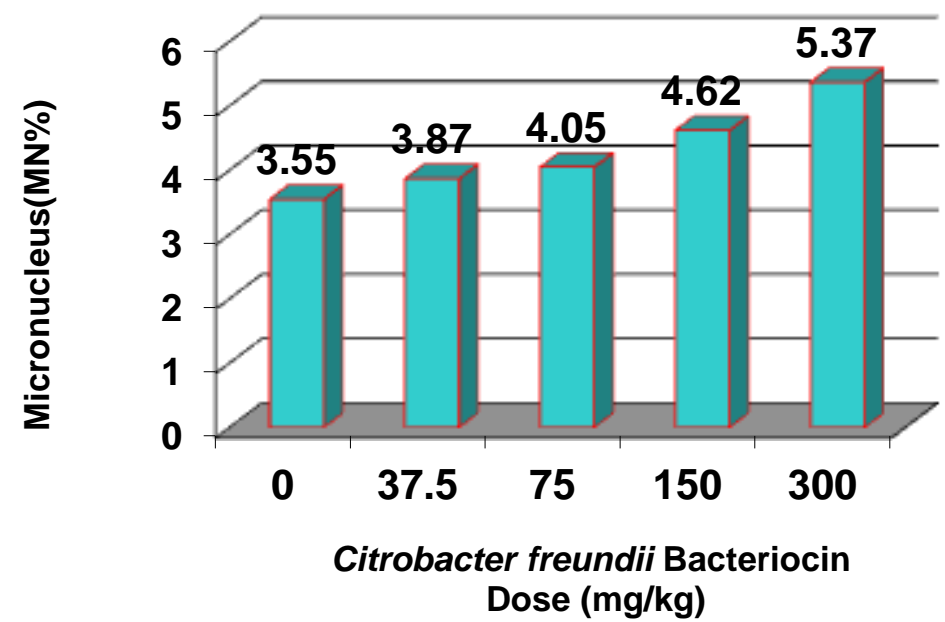

Figure 1-Effect of $C$. freundii bacteriocin on Frequency of Micronuclei (MN\%) in bone marrow cells.

\section{Effect of $C$. freundii bacteriocin on DNA damage by comet assay}

\section{Tail length}

Figure-2 shows a significant increase in tail length value in the treated mice for the doses of 75 , 150 and $300 \mathrm{mg} / \mathrm{kg}(145.18 \pm 11.92,267.73 \pm 14.06$ and $295.08 \pm 234.58 \%$, respectively) as compared to the control $(6.36 \pm 0.71 \%)$. While no significant differences were observed at the dose of $37.5 \mathrm{mg} / \mathrm{kg}$ in comparison with the control. Whereas, when the comparison was made among the doses $(37.5,75,150$ and $300 \mathrm{mg} / \mathrm{kg}$ ), the results showed a significant increase in tail length value $(295.08 \pm 234.58 \%)$ at the dose of $300 \mathrm{mg} / \mathrm{kg}(\mathrm{P} \leq 0.05)$.

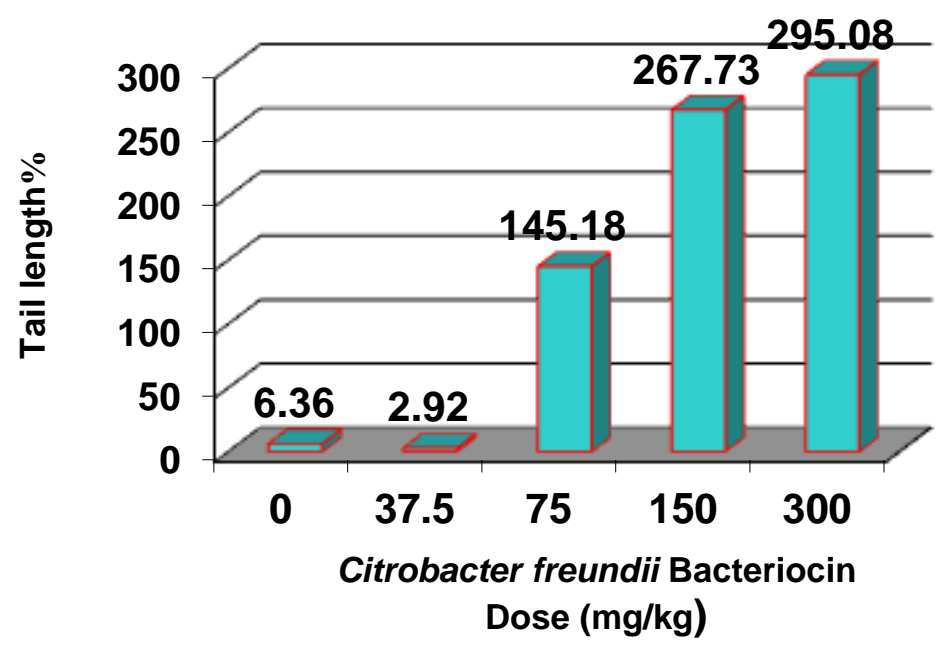

Figure 2-Effect of $C$. freundii bacteriocin on DNA damage (Tail length).

\section{Percentage of DNA in tail}

Results in Figure-3 show significant increases $(\mathrm{P} \leq 0.05)$ at higher doses of 150 and $300 \mathrm{mg} / \mathrm{kg}$ (13.87 \pm 1.04 and $14.31 \pm 1.11 \%$, respectively) in comparison with the control $(2.17 \pm 0.19 \%)$. In addition, no significant differences were noted with the dose of $37.5 \mathrm{mg} / \mathrm{kg}$ ), while a significant increase was recorded at dose the dose of $75 \mathrm{mg} / \mathrm{kg}(8.05 \pm 0.32 \%)$. Moreover, significant differences were observed when comparing the lower $(37.5$ and $75 \mathrm{mg} / \mathrm{kg}$ ) and the higher doses, with the value reaching $14.31 \pm 1.11 \%$ at the dose of $300 \mathrm{mg} / \mathrm{kg}$. 


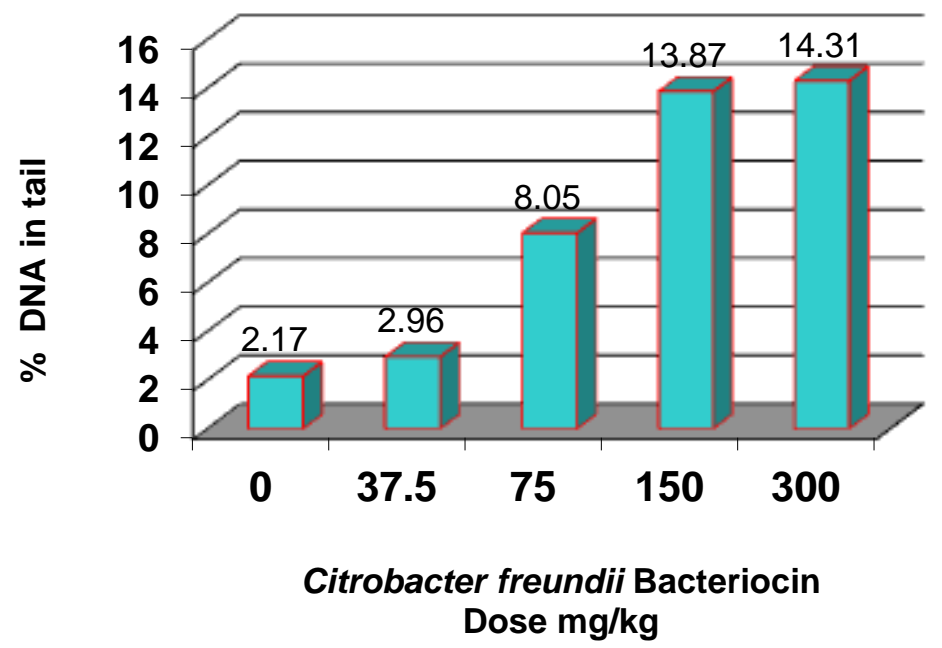

Figure 3-Effect $C$. freundii bacteriocin on DNA damage (\%DNA in tail).

\section{Olive tail moment}

Results in Figure-4 reveal a significant increase $(\mathrm{P} \leq 0.05)$ in olive moment values in mice treated with $C$. freundii bacteriocin at higher doses of 150 and $300 \mathrm{mg} / \mathrm{kg}$ with $(22.72 \pm 1.71$ and $25.85 \pm$ $3.06 \%$, respectively) in comparison to the control $(0.981 \pm 0.08 \%)$. However, no significant differences were found between the control $(1.058 \pm 0.12 \%)$ and the lower dose $(37.5 \mathrm{mg} / \mathrm{kg})$. The comparison among the doses $(37.5,75,150$ and $300 \mathrm{mg} / \mathrm{kg}$ ) recorded significant increases, reaching a highest value of $25.85 \pm 3.06 \%$ at the dose of $300 \mathrm{mg} / \mathrm{kg}$.

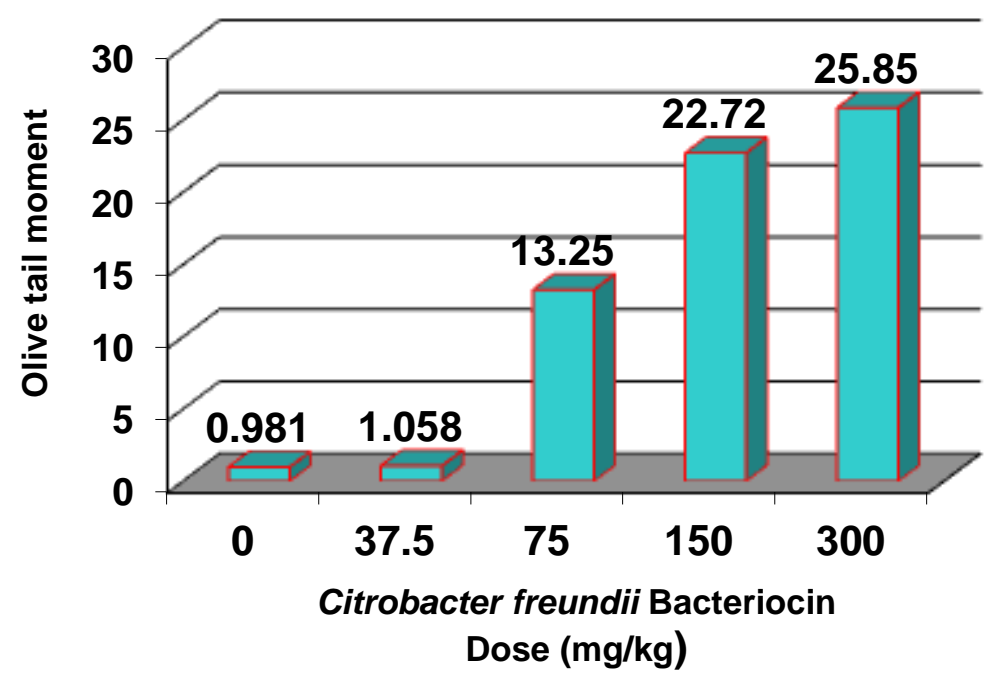

Figure 4-Effect $C$. freundii bacteriocin on DNA damage (Olive tail moment).

Single cell gel (SCG) is implemented to detect DNA damages using the alkaline method that allows the detection of double and single strand breaks and alkali-labile sites. It became the most used approach due to its broad- spectrum of detection of DNA damage. Comet assay allows to detect breaks in DNA strands in both interphase and mitotic cells, which can be visualized by the increased migration of free DNA segments, resulting in images similar to comets. This method was used by a number of investigators to trace DNA defects and to determine the quantity of DNA by measuring the exchanges between the genetic material of the nucleus and the consequent tail [34].

Alkaline comet assay of analysis of DNA content in the comet tail was used to demonstrate the effect on DNA integrity and chromosomal damages (Figure-5), bridges, fragments and other types of disorders, in the interphase nuclei of murine bone marrow cells after acute exposure to these 
bacteriocin types. Nevertheless, the mechanism of these effects on DNA integrity remains unknown. Probably, the detected effect is caused by the non-adaptation of the animals to the chemosignal used at the level of the bone marrow interphase nuclei. It is also possible that the damaged cells will accumulate after $24 \mathrm{~h}$ due to their inability to enter mitosis [37, 38].

Accordingly, comet assay was used to evaluate DNA damages in apoptotic cells due to its easy implementation and low costs. Although the comet assay has been used to predict apoptosis, the presence of hedgehog comets, characterized by a small head and a long or absent tail, is not considered as an apoptotic indicator. It is well established that necrosis also leads to DNA fragmentation $[39,34]$.

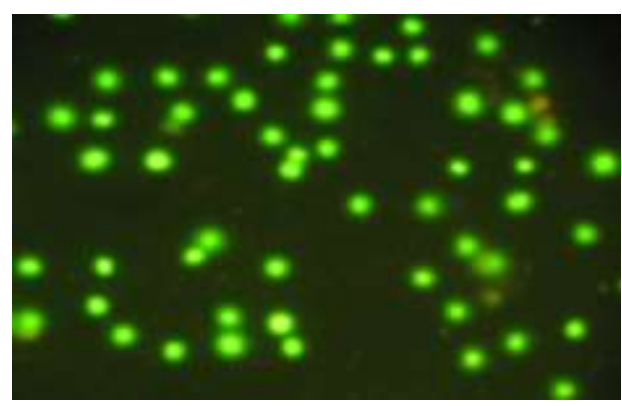

A. Normal DNA

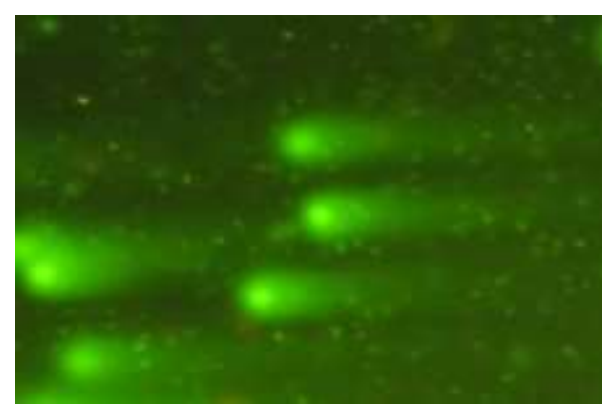

B. Effected DNA

Figure 5-DNA from bone marrow cells of albino mice exposed to C. freundii Bacteriocin A. Normal DNA: refers to DNA without damage B. Affected DNA: refers to DNA with damage.

\section{Conclusion}

The micronucleus ( $\mathrm{MN}$ ) and comet assays has been $\mathrm{t}$ widely used as the most reliable and sensitive in vivo approaches to assess the induction of chromosomal aberrations and strand breaks in DNA which is caused $C$. freundii bacteriocin.

\section{Recommendations}

Further studies should be performed to investigate the effect of $C$. freundii bacteriocin on the level of nucleotides, to show mutagenicity of changes in the sequence of standard base pairs or abnormal chemical structure in DNA.

\section{References}

1. Whalen, J. G., Mully, T. W. and English, J. C. 2007. Spontaneous Citrobacter freundii infection in an immunocompetent patient. Archives of dermatology, 143(1): 115-126..

2. Park, S., Song, S. H., Lee, C., Kim, J. W. and Kim, K. S. 2013. Bacterial pathogens in first febrile urinary tract infection affect breakthrough infections in infants with vesicoureteral reflux treated with prophylactic antibiotics. Urology, 81(6): 1342-1345.

3. Riley, M.A. and Wertz, J.E. 2002. BACTERIOCINS: Evolution, Ecology, and Application. Annual Reviews in Microbiology. 56: 117-137.

4. Yang, S. C., Lin, C. H., Sung, C. T. and Fang, J. Y. 2014. Antibacterial activities of bacteriocins: application in foods and pharmaceuticals. Frontiers in microbiology, 5: 241.

5. Vasilchenko, A. S. and Valyshev, A. V. 2019. Pore-forming bacteriocins: structural-functional relationships. Archives of microbiology, 201(2): 147-154.

6. Riley, M. A. and Chavan, M. A. 2007. Bacteriocins. Springer-Verlag Berlin Heidelberg.

7. Balciunas, E. M., Martinez, F. A. C., Todorov, S. D., de Melo Franco, B. D. G., Converti, A. and de Souza Oliveira, R. P. 2013. Novel biotechnological applications of bacteriocins: a review. Food Control, 32(1): 134-142.

8. Manning, J., Dunne, E. M., Wescombe, P. A., Hale, J. D., Mulholland, E. K., Tagg, J. R. and Satzke, C. 2016. Investigation of Streptococcus salivarius-mediated inhibition of pneumococcal adherence to pharyngeal epithelial cells. BMC microbiology, 16(1): 225.

9. Alvarez-Sieiro, P., Montalbán-López, M., Mu, D. and Kuipers, O. P. 2016. Bacteriocins of lactic acid bacteria: extending the family. Applied microbiology and biotechnology, 100(7): 2939-2951. 
10. Mathur, H., C Rea, M., D Cotter, P., Hill, C., and Paul Ross, R. 2015. The sactibiotic subclass of bacteriocins: an update. Current Protein and Peptide Science, 16(6): 549-558.

11. Al-mawlawi, Z. S. and Obaid, H. H. 2017. Antibacterial Activity of Synergistic Effect of Colicin and Gold Nanoparticles Against Pseudomonas Aerugensa. Iraqi Journal of Science, 58(2C): 10201027.

12. Al-mawlawi, Z. S. and Obaid, H. H. 2019. Antibacterial Activity of Synergistic Effect of colicin and Gold Nanoparticles against Klebsiella pneumonia. SCOPUS IJPHRD CITATION SCORE, 10(01): 1041.

13. Harkness, R. E. and Braun, V. 1990(b). In Vitro Peptidoglycan Synthesis by Envelopes from E. coli tol M Mutants Is Inhibited by Colicin M. J. of Bacterol., 172: 498- 500.

14. Chumchalova, J. and Smarda, J. 2001. Colicins and their effect on malignant cells. ScriptaMedica, 74: 273-300.

15. Smarda, J. and Smajs, D. 1998. Colicins-Exocellular Lethal Proteins of Escherichia coli. Folia Microbiol, 43: 563-82.

16. Cursino, L., Chartone-Souza, E., and Nascimento, A. 2002. Recent updated aspects of colicins of Enterobacteriaceae. Brazilian Journal of Microbiology, 33(3): 185-195.

17. 17. Obaid, H. H., Essa, H. R. and Yaseen, N. Y. 2010 Cytotoxicity of non-bound colicins extracted from Escherichia coli on normal white blood cells and myeloblast isolated from acute myeloid leukemia blood patients, Iraqi Journal of Science, 51(4): 528-538.

18. Cebrián, R., Rodríguez-Cabezas, M. E., Martín-Escolano, R., Rubiño, S., Garrido-Barros, M., Montalbán-López, M. and Marín, C. 2019. Preclinical studies of toxicity and safety of the AS-48 bacteriocin. Journal of advanced research, 20: 129-139.

19. Smarda, J.; Ebringer, L. and Mach, J. 1975. The Effect of Colicin E2 on the Flagellate Euglena gracilis. J. Gen Microbiol., 86: 363- 6.

20. Naghmouchi, K., Baah, J., Hober, D., Jouy, E., Rubrecht, C., Sané, F. and Drider, D. 2013. Synergistic effect between colistin and bacteriocins in controlling Gram-negative pathogens and their potential to reduce antibiotic toxicity in mammalian epithelial cells. Antimicrobial agents and chemotherapy, 57(6): 2719-2725.

21. Koneman, E. W., Allen, S. D., Janda, W. M., Schreckenberger, P. C. and Winn, W. C. 1997. The enterobacteriaceae. Color atlas and textbook of diagnostic microbiology, 5: 211-302.

22. Al-Qassab, A. O. and Al-Khafaji, Z. M. 1992. Effect of different conditions on inhibition activity of enteric lactobacilli against diarrhea-causing enteric bacteria. J. Agri. Sci, 3(1): 18-26.

23. Herschman, H. R. and Helinski, D. R. 1967. Purification and characterization of colicin E2 and colicin E3. Journal of Biological Chemistry, 242(22): 5360-5368.

24. Smajs, D., Pilsl, H. and Braun, V. 1997. Colicin U, AnovelColicin Produced by Shigellaboydii. J. of Bacteriol, 179: 4919- 28.

25. Lowry, O. H.; Rosebrough, N. J.; Farr, A. L. and Randall, R. J. 1951. Protien Measurement with the Folin Phenol Reagent. J. Biol. Chemical., 193: 265- 75.

26. Dixon, W. J. 1980. Efficient analysis of experimental observations. Annual review of pharmacology and toxicology, 20(1): 441-462.

27. Allen, J.M.; Shuler, C.V.; Mendes, R.W. and Latt, S.A. 1977. A simplified technique for in vivo analysis of sister chromatid exchanges 5-bomo-deoxy uridine tablets. Cytogentics and cell Genetics. 18: 231-237.

28. Schmid, W. 1975. The micronucleus test. Mutat. Res./Environ. Mutagenes. Relat. Subj, 31: 9-15.

29. Singh, N. P., McCoy, M. T., Tice, R. R., and Schneider, E. L. 1988. A simple technique for quantitation of low levels of DNA damage in individual cells. Experimental cell research, 175(1): 184-191.

30. Gontijio, A.; Elias, F.; Salvadori, D.; Oliveira, M.; Correa, L. and Goldberg, J. 2001. Single cell gel comet assay detects primary DNA damage in nonneoplasticurothelial cells of smokers and Ex smokers. Cancer Epidemiology biomarkers and prevention, 10: 987-993.

31. SAS. 2012. Statistical Analysis System, User's Guide. Statistical. Version 9.1th ed. SAS. Inst. Inc. Cary. N.C. USA.

32. Krishna, G., and Hayashi, M. 2000. In vivo rodent micronucleus assay: protocol, conduct and data interpretation. Mutation Research/Fundamental and Molecular Mechanisms of Mutagenesis, 455(1-2): 155-166. 
33. Samanta, S., and Dey, P. 2012. Micronucleus and its applications. Diagnostic cytopathology, 40(1), 84-90.

34. Araldi, R. P., de Melo, T. C., Mendes, T. B., de SáJúnior, P. L., Nozima, B. H. N., Ito, E. T. and de Cassia Stocco, R. 2015. Using the comet and micronucleus assays for genotoxicity studies: a review. Biomedicine \& Pharmacotherapy, 72: 74-82.

35. Mavournin, K. H., Blakey, D. H., Cimino, M. C., Salamone, M. F., and Heddle, J. A. 1990. The in vivo micronucleus assay in mammalian bone marrow and peripheral blood. A report of the US Environmental Protection Agency Gene-Tox Program. Mutation Research/Reviews in Genetic Toxicology, 239(1): 29-80.

36. Bannister, L., Mantha, R., Devantier, Y., Petoukhov, E., Brideau, C., Serran, M., \&Klokov, D. 2016. Dose and radioadaptive response analysis of micronucleus induction in mouse bone marrow. International journal of molecular sciences, 17(9): 1548.

37. Daev, E. V. 2007. Stress, chemocommunication, and the physiological hypothesis of mutation. Russian Journal of Genetics, 43(10): 1082-1092.

38. Daev, E. V., Petrova, M. V., Onopa, L. S., Shubina, V. A. and Glinin, T. S. 2017. Dna Damage In Bone Marrow Cells Of Mouse Males In Vivo After Exposure To The Pheromone: Comet Assay. Russian Journal of Genetics, 53(10): 1105-1112.

39. Azqueta, A. and Collins, A. R. 2013. The essential comet assay: a comprehensive guide to measuring DNA damage and repair. Archives of toxicology, 87(6): 949-968. 